\title{
Boric acid as a mild and efficient catalyst for one-pot synthesis of 1-amidoalkyl-2-naphthols under solvent-free conditions
}

\author{
AZIZ SHAHRISA*, SOMAYEH ESMATI and MAHDI GHOLAMHOSSEINI NAZARI \\ Department of Organic Chemistry and Biochemistry, Faculty of Chemistry, University of Tabriz, \\ Tabriz 5166614766, Iran \\ e-mail: ashahrisa@yahoo.com
}

MS received 2 March 2011; revised 14 November 2011; accepted 19 March 2012

\begin{abstract}
An efficient green chemistry method has been developed for the synthesis of 1-amidoalkyl-2naphthol derivatives via a one-pot three-component condensation of 2-naphthol, aldehydes and amide in the presence of boric acid as a mild catalyst.
\end{abstract}

Keywords. Multicomponent reaction; amidoalkyl naphthol; boric acid; catalyst; solvent-free synthesis.

\section{Introduction}

Multicomponent reactions (MCRs), in which three or more reactants are combined in a one-pot process, have become an efficient and powerful tool for the construction of complex molecules. ${ }^{1}$ In recent years, MCRs have attracted extensive efforts by researchers in modern synthetic chemistry because they increase the efficiency by combining several operational steps without the isolation of intermediates or changing the reaction conditions. The development and application of MCRs are now an integral part of the work of any major medical research unit. ${ }^{2}$

1-Amidoalkyl-2-naphthol derivatives are of significant medical relevance since they can be converted into hypertensive and bradycardia active 1-aminoalkyl2-naphthols by amide hydrolysis reaction. ${ }^{3}$ The preparation of amidoalkyl naphthols can be carried out by multicomponent condensation of aldehydes, 2-naphthol and amides in the presence of Lewis or Brønsted acid catalysts such as montmorillonite $\mathrm{K} 10$ clay, ${ }^{4} \mathrm{Ce}\left(\mathrm{SO}_{4}\right)_{2},{ }^{5}$ $\mathrm{K}_{5} \mathrm{CoW}_{12} \mathrm{O}_{40} \cdot 3 \mathrm{H}_{2} \mathrm{O},{ }^{6}$ iodine, ${ }^{7} \mathrm{ZrOCl}_{2} \cdot 8 \mathrm{H}_{2} \mathrm{O},{ }^{8}$ sulphamic acid, ${ }^{9}$ silica-supported perchloric acid, ${ }^{10} \mathrm{Fe}\left(\mathrm{HSO}_{4}\right)_{3},{ }^{11}$ $\mathrm{P}_{2} \mathrm{O}_{5},{ }^{12} \mathrm{FeCl}_{3} \cdot \mathrm{SiO}_{2},{ }^{13}$ silica-sodium hydrogen sulphate, ${ }^{14}$ molybdophosphoric acid $\left(\mathrm{H}_{3}\left[\mathrm{P}\left(\mathrm{Mo}_{3} \mathrm{O}_{10}\right)_{4}\right]\right),{ }^{15}$ p-toluenesulphonic acid, ${ }^{16} \mathrm{H}_{3} \mathrm{PW}_{12} \mathrm{O}_{40},{ }^{17}$ silicotungstic acid $\left(\mathrm{H}_{4} \mathrm{SiW}_{12} \mathrm{O}_{40}\right),{ }^{18}$ wet cyanuric chloride, ${ }^{19}$ perchloric acid supported on alumina $\left(\mathrm{Al}_{2} \mathrm{O}_{3}-\mathrm{HClO}_{4}\right),{ }^{20} \mathrm{~N}, \mathrm{~N}$, $N^{\prime}, N^{\prime}$-tetrabromobenzene-1,3-disulphonamide [TBBDA], ${ }^{21}$ trityl chloride, ${ }^{22} \mathrm{Cu}$-exchanged heteropoly acids, ${ }^{23}$ cation-exchange resins, ${ }^{24}$ silica chloride, ${ }^{25}$ Hafnium (IV) bis(perfluorooctanesulphonyl)imide complex ${ }^{26}$ cop-

*For correspondence per $p$-toluenesulphonate, ${ }^{27}$ 2,4,6-trichloro-1,3,5-triazine, ${ }^{28}$ Zeolite, ${ }^{29}$ Indium chloride, ${ }^{30}$ zinc benzenesulphonate ${ }^{31}$ and ionic liquids. ${ }^{32}$ However, some of the reported methods suffer from disadvantages such as long reaction time, the use of toxic, corrosive, expensive or non-reusable catalysts, low yields of products, the use of large amount of catalyst and strongly acidic conditions. Therefore, to overcome these limitations, the discovery of a new, inexpensive, easily available catalyst with high catalytic activity and short reaction time for the preparation of amidoalkyl naphthols is essential.

In recent years, boric acid has been used in organic synthesis because it is commercially available, environmentally benign, cheap, easy to handle, and stable. Boric acid has been utilized in numerous reactions, for example, aza-Michael ${ }^{33}$ and thia-Michael reactions, ${ }^{34}$ transesterification of ethyl acetoacetate, ${ }^{35}$ preparation of $\alpha$-hydroxyamides, ${ }^{36}$ oxidation of sulphides, ${ }^{37} \mathrm{Big}$ inelli reaction, ${ }^{38}$ synthesis of 1,5 -benzodiazepine derivatives, ${ }^{39}$ and synthesis of 2-amino-3,5-dicarbonitrile-6-thio-pyridines. ${ }^{40}$ It is therefore of interest to examine the behaviour of boric acid as catalyst in the synthesis of amidoalkyl naphthols. In this work, we describe a new and convenient synthesis of amidoalkyl naphthols by multicomponent reaction of 2-naphthol, aromatic aldehydes and acetamide catalysed by boric acid under solvent-free conditions (scheme 1).

\section{Experimental}

All chemicals were purchased from Merck and Fluka Chemical Companies. Melting points were determined on a MEL-TEMP model 1202D and are uncorrected. 


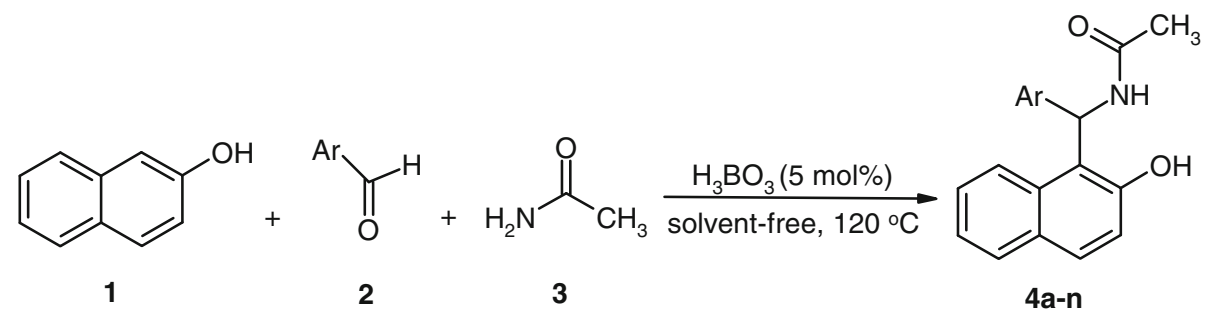

Scheme 1. Synthesis of 1-amidoalkyl-2-naphthols using boric acid.

FT-IR spectra were recorded on a Bruker Tensor 27 spectrometer as $\mathrm{KBr}$ disks. The ${ }^{1} \mathrm{H}$ NMR spectra were recorded with a Bruker Spectrospin Avance 400 spectrometer. ${ }^{13} \mathrm{C}$ NMR spectra were determined on the same instrument at $100 \mathrm{MHz}$. All chemical shifts are reported in $\delta(\mathrm{ppm})$ relative to solvent peaks as an internal standard and coupling constants $(J)$ are given in $\mathrm{Hz}$.

\subsection{General procedure for the synthesis of amidoalkyl naphthols}

To a mixture of aldehyde (1 mmol), 2-naphthol (1 mmol) and acetamide $(1.2 \mathrm{mmol})$ boric acid $(5 \mathrm{~mol} \%)$ was added. The mixture was stirred at $120^{\circ} \mathrm{C}$ in an oil bath and the completion of reaction was monitored by TLC (acetone/n-hexane: 1/3). After completion of the reaction, the mixture was cooled to room temperature, and water $(10 \mathrm{ml})$ was added, and the mixture was stirred for $10 \mathrm{~min}$. The solid obtained was collected by filtration and purified by recrystallization from ethanol.

\subsection{Spectral data of selected products}

2.2a $N$-[(2-Hydroxynaphthalen-1-yl)(4-chlorophenyl) methyl]acetamide(4d): Pale yellow solid; mp 236$238^{\circ} \mathrm{C}$ (lit. $\left.{ }^{12} \mathrm{mp} 237-238^{\circ} \mathrm{C}\right) ;{ }^{1} \mathrm{H}$ NMR $(400 \mathrm{MHz}$, DMSO-d 6 ): $\delta(\mathrm{ppm}) 1.99$ (s, 3H), $7.11(\mathrm{~d}, J=8.1 \mathrm{~Hz}$, $1 \mathrm{H}), 7.16(\mathrm{~d}, J=8.3 \mathrm{~Hz}, 2 \mathrm{H}), 7.22-7.28(\mathrm{~m}, 2 \mathrm{H})$,

Table 1. Preparation of 1-amidoalkyl-2-naphthol under various conditions.

\begin{tabular}{lcc}
\hline Solvent & Time/condition & Yield\% \\
\hline $\mathrm{CHCl}_{3}$ & $24 \mathrm{~h} /$ reflux & 71 \\
$\mathrm{CH}_{2} \mathrm{Cl}_{2}$ & $24 \mathrm{~h} /$ reflux & 75 \\
$\mathrm{MeOH}$ & $24 \mathrm{~h} /$ reflux & 60 \\
$\mathrm{EtOH}$ & $24 \mathrm{~h} /$ reflux & 56 \\
$\mathrm{DMF}$ & $24 \mathrm{~h} / \mathrm{reflux}$ & 15 \\
$1,4-\mathrm{Dioxane}$ & $24 \mathrm{~h} /$ reflux & 65 \\
$\mathrm{THF}$ & $24 \mathrm{~h} / \mathrm{reflux}$ & 61 \\
Solvent-free & $7 \mathrm{~min} / 110^{\circ} \mathrm{C}$ & 88 \\
\hline
\end{tabular}

$7.31(\mathrm{~d}, J=8.3 \mathrm{~Hz}, 2 \mathrm{H}), 7.37(\mathrm{t}, J=6.9 \mathrm{~Hz}, 1 \mathrm{H})$, 7.76-7.81 (m, 3H), $8.50(\mathrm{~d}, J=8.1 \mathrm{~Hz}, 1 \mathrm{H}), 10.09$ $(\mathrm{s}, 1 \mathrm{H}) ;{ }^{13} \mathrm{C}$ NMR $\left(100 \mathrm{MHz}, \mathrm{DMSO}-\mathrm{d}_{6}\right): 22.3,47.1$, 118.1, 118.2, 122.2, 122.8, 126.2, 127.6, 127.7, 128.2, $128.3,129.2,130.4,131.9,141.5,152.9,169.2 \mathrm{ppm}$; FT-IR $\left(\mathrm{KBr}, \mathrm{cm}^{-1}\right): 3387,2963,1629,1519,1434$, 1081, 809, 748 .

2.2b N-[(2-Hydroxynaphthalen-1-yl)(3-bromophenyl) methyl]acetamide(4f): White solid; mp $229-230^{\circ} \mathrm{C}$; ${ }^{1} \mathrm{H}$ NMR (400 MHz, DMSO-d ${ }_{6}$ ): $\delta$ (ppm) 1.99 (s, $3 \mathrm{H}), 7.08-7.42(\mathrm{~m}, 8 \mathrm{H}), 7.74-7.83(\mathrm{~m}, 3 \mathrm{H}), 8.52(\mathrm{~d}$, $J=8.2 \mathrm{~Hz}, 1 \mathrm{H}), 10.09$ (s, 1H); ${ }^{13} \mathrm{C}$ NMR $(100 \mathrm{MHz}$, DMSO- $\left.\mathrm{d}_{6}\right): 22.6,47.4,118.2,118.4,121.5,122.5$, $122.9,125.2,126.6,128.4,128.5,128.6,128.9,129.6$, 130.0, 132.2, 145.7, 153.2, 169.5 ppm; FT-IR (KBr, $\left.\mathrm{cm}^{-1}\right)$ : 3408, 3062, 1639, 1509, 1434, 1065, 807, 749; Anal. Calcd. for $\mathrm{C}_{19} \mathrm{H}_{16} \mathrm{BrNO}_{2} \%$ : C: $61.64, \mathrm{H}: 4.36, \mathrm{~N}$ : 3.78. Found: C: $61.32, \mathrm{H}: 4.45, \mathrm{~N}: 3.71 \%$.

2.2c N-[(2-Hydroxynaphthalen-1-yl)(thiophen-2-yl) methyl]acetamide(4l): Pale yellow solid; mp 224$225^{\circ} \mathrm{C} ;{ }^{1} \mathrm{H}$ NMR (400 MHz, DMSO-d 6 ): $\delta(\mathrm{ppm}) 1.94$ $(\mathrm{s}, 3 \mathrm{H}), 6.73(\mathrm{~d}, J=2.7 \mathrm{~Hz}, 1 \mathrm{H}), 6.87-6.89(\mathrm{~m}, 1 \mathrm{H})$, $7.21-7.31(\mathrm{~m}, 4 \mathrm{H}), 7.39(\mathrm{t}, J=6.7 \mathrm{~Hz}, 1 \mathrm{H}), 7.76-7.82$ $(\mathrm{m}, 2 \mathrm{H}), 7.92(\mathrm{~d}, J=8.0 \mathrm{~Hz}, 1 \mathrm{H}), 8.64(\mathrm{~d}, J=8.0 \mathrm{~Hz}$, $1 \mathrm{H}), 10.17(\mathrm{~s}, 1 \mathrm{H}) ;{ }^{13} \mathrm{C}$ NMR $(100 \mathrm{MHz}$, DMSO$\left.\mathrm{d}_{6}\right)$ : $21.3,43.7,117.0,117.1,121.2,121.8,122.7$, 123.1, 125.1, 125.3, 127.1, 127.3, 128.3, 130.7, 145.7, 151.8, 167.7 ppm; FT-IR $\left(\mathrm{KBr}, \mathrm{cm}^{-1}\right)$ : 3386, 3234,

Table 2. Optimization of temperature and amount of boric acid.

\begin{tabular}{lcccc}
\hline Entry & $\begin{array}{c}\text { Catalyst } \\
(\mathrm{mol} \%)\end{array}$ & $\begin{array}{c}\text { Temperature } \\
\left({ }^{\circ} \mathrm{C}\right)\end{array}$ & $\begin{array}{c}\text { Time } \\
(\mathrm{min})\end{array}$ & $\begin{array}{c}\text { Yield } \\
(\%)\end{array}$ \\
\hline 1 & 10 & 100 & 9 & 78 \\
2 & 10 & 110 & 7 & 88 \\
3 & 10 & 120 & 5 & 90 \\
4 & 10 & 130 & 5 & 86 \\
5 & 15 & 120 & 6 & 84 \\
6 & 5 & 120 & 4 & 92 \\
\hline
\end{tabular}


Table 3. Synthesis of 1-amidoalkyl-2-naphthols catalysed by $\mathrm{H}_{3} \mathrm{BO}_{3}$.

\begin{tabular}{|c|c|c|c|c|c|}
\hline Entry & Aldehyde & Product & $\begin{array}{l}\text { Time } \\
(\mathrm{min})\end{array}$ & $\begin{array}{l}\text { Yield } \\
(\%)\end{array}$ & $\begin{array}{c}\text { M.P. }\left({ }^{\circ} \mathrm{C}\right) \\
\left(\text { lit. m.p. }\left({ }^{\circ} \mathrm{C}\right)\right)^{\text {ref }}\end{array}$ \\
\hline 1 & & $4 a$ & 4 & 92 & $\begin{array}{c}237-238 \\
(237-238)^{12}\end{array}$ \\
\hline 2 & & $4 b$ & 4 & 89 & $\begin{array}{l}254-256 \\
(256-258)^{12}\end{array}$ \\
\hline 3 & & $4 c$ & 6 & 82 & $\begin{array}{c}218-219 \\
(218-219)^{12}\end{array}$ \\
\hline 4 & & $4 d$ & 5 & 91 & $\begin{array}{l}236-238 \\
(237-238)^{12}\end{array}$ \\
\hline 5 & & $4 e$ & 7 & 90 & $\begin{array}{l}204-205 \\
(206-207)^{12}\end{array}$ \\
\hline 6 & & $4 f$ & 7 & 93 & $229-230$ \\
\hline 7 & & $4 g$ & 10 & 92 & 190-191 \\
\hline 8 & & $4 h$ & 6 & 80 & $\begin{array}{l}244-245 \\
(245-246)^{11}\end{array}$ \\
\hline 9 & & $4 \mathbf{i}$ & 12 & 77 & $\begin{array}{c}182-183 \\
(183-185)^{11}\end{array}$ \\
\hline 10 & & $\mathbf{4 j}$ & 10 & 82 & $\begin{array}{c}223-225 \\
(224-225)^{12}\end{array}$ \\
\hline 11 & & $4 k$ & 12 & 86 & $216-218$ \\
\hline 12 & & 41 & 10 & 75 & $224-225$ \\
\hline 13 & & $4 m$ & 9 & 91 & $220-222$ \\
\hline 14 & & $4 n$ & 10 & 80 & $218-219$ \\
\hline
\end{tabular}


1638, 1507, 1429, 1091, 807, 740; Anal. Calcd. for $\mathrm{C}_{17} \mathrm{H}_{15} \mathrm{NO}_{2} \mathrm{~S} \%$ : C: $68.66, \mathrm{H}: 5.08, \mathrm{~N}: 4.71, \mathrm{~S}: 10.78 \%$. Found: C: $68.45, \mathrm{H}: 5.26, \mathrm{~N}: 4.68, \mathrm{~S}: 10.65 \%$.

$2.2 \mathrm{~d} \quad \mathrm{~N}-[(2-H y d r o x y n a p h t h a l e n-1-y l)(2-c h l o r o-6-$ flourophenyl) methyl] acetamide (4n): White solid; mp $218-219^{\circ} \mathrm{C} ;{ }^{1} \mathrm{H}$ NMR (400 MHz, DMSO- $\left.\mathrm{d}_{6}\right): \delta$ (ppm) $1.88(\mathrm{~s}, 3 \mathrm{H}), 7.05-7.31(\mathrm{~m}, 6 \mathrm{H}), 7.47(\mathrm{t}, J=$ $7.2 \mathrm{~Hz}, 1 \mathrm{H}), 7.73(\mathrm{~d}, J=8.7 \mathrm{~Hz}, 1 \mathrm{H}), 7.80(\mathrm{~d}, J=$ $8.0 \mathrm{~Hz}, 1 \mathrm{H}), 7.97(\mathrm{~d}, J=8.7 \mathrm{~Hz}, 1 \mathrm{H}), 8.59(\mathrm{~d}, J$ $=8.3 \mathrm{~Hz}, 1 \mathrm{H}), 9.77(\mathrm{~s}, 1 \mathrm{H}) ;{ }^{13} \mathrm{C}$ NMR $(100 \mathrm{MHz}$, DMSO-d 6 ): 21.9, 45.9, 114.48, 114.72, 115.6, 118.4, $121.8,122.1,124.8,126.4,127.8,128.0,128.1$, $128.3,128.4,129.4,132.6,132.8,132.9,153.6,160.9$, 163.4, 168.3 ppm; FT-IR $\left(\mathrm{KBr}, \mathrm{cm}^{-1}\right): 3429,3285$, 1644, 1517, 1444, 1102, 813, 775; Anal. Calcd. for $\mathrm{C}_{19} \mathrm{H}_{15} \mathrm{ClFNO}_{2} \%$ : C: $66.38, \mathrm{H}: 4.40, \mathrm{~N}: 4.07$. Found: C: $66.14, \mathrm{H}: 4.54, \mathrm{~N}: 3.98 \%$.

\section{Results and discussion}

To optimize the reaction conditions, the reaction of 2naphthol (1 mmol), 4-nitrobenzaldehyde $(1 \mathrm{mmol})$ and acetamide $(1.2 \mathrm{mmol})$ was selected as a model reaction and carried out in various solvents and under solventfree condition in the presence of $10 \mathrm{~mol} \%$ of boric acid. As shown in table 1, higher yield and shorter reaction time was obtained under solvent-free condition.

Furthermore, the model reaction catalysed by 10 mol\% of boric acid was studied at different temperatures (table 2, entries 1-4). The reaction rate was increased as the reaction temperature was raised. When it was carried out at $120^{\circ} \mathrm{C}$, the maximum yield was obtained in a short reaction period (table 2, entry 3 ).

In another study, the condensation reaction of 2-naphthol, 4-nitrobenzaldehyde and acetamide was examined in the presence of different quantities of boric acid at $120^{\circ} \mathrm{C}$ (table 2, entries 3,5,6). As table 2 indicates, the reasonable result was obtained when the reaction was performed using $5 \mathrm{~mol} \%$ of boric acid (entry 6). No improvement in the reaction yield was observed by increasing the amount of boric acid to $15 \mathrm{~mol} \%$ (entry 5).

To demonstrate the scope of the procedure, the condensation of 2-naphthol with various arylaldehydes and acetamide was examined in the presence of boric acid (5 mol\%) at $120^{\circ} \mathrm{C}$ under solvent free condition. The corresponding results are displayed in table 3 . As it can be seen in table 3 , the reactions were carried out efficiently within 4-12 min and the desired products were produced in good to high yields. The formation of products were confirmed by physical and spectroscopic data and are in good agreement with the reported one. ${ }^{11,12}$ Thus, boric acid is an efficient, and mild catalyst for the preparation of 1-amidoalkyl-2-naphthols.

We propose the following mechanism for $\mathrm{H}_{3} \mathrm{BO}_{3}$ catalysed condensation reaction as shown in scheme 2 . The condensation of 2-naphthol, aldehyde and amide may occur by a combined mechanism involving addition, dehydration, and Michael addition. It seems that boric acid increases the electrophilicity of aldehyde considerably.

\section{Conclusions}

In summary, we have developed very simple, mild, convenient and efficient method for the synthesis of amidoalkyl-2-naphthols by one-pot three-component condensation of aromatic and heteroaromatic aldehydes, 2-naphthol and acetamide using $\mathrm{H}_{3} \mathrm{BO}_{3}$ as a green catalyst under solvent free condition. The operational simplicity of the procedure, short reaction times, easy workup and environmental friendliness (non-corrosive catalyst) makes this method highly attractive.

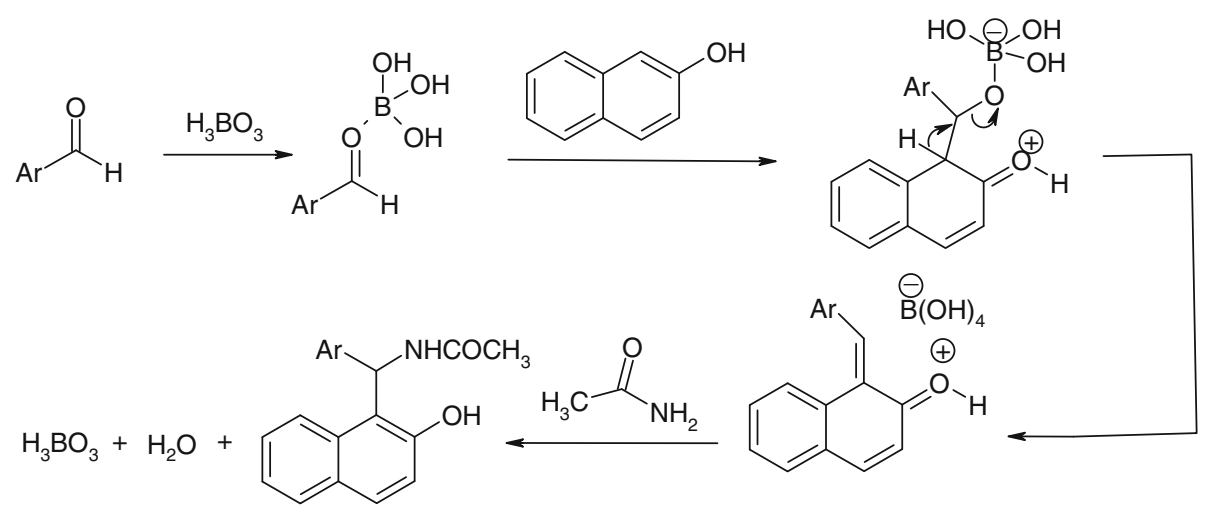

Scheme 2. Proposed mechanism for the synthesis of 1-amidoalkyl-2-naphthol. 


\section{Acknowledgement}

We thank Research Affairs of the University of Tabriz for financial support.

\section{References}

1. (a) Rubin Y, Lin S S, Knobler C B, Anthony J, Boldi A M and Diederich F 1991 J. Am. Chem. Soc. 113 6943; (b) Domling A 2006 Chem. Rev. 10617

2. (a) Heravi M M, Baghernejad B and Oskooie H A 2009 Tetrahedron Lett. 50 767; (b) Huang X and Zhang T 2009 Tetrahedron Lett. 50 208; (c) Cui S, Wang J and Wang Y 2008 Org. Lett. 10 1267; (d) Zhu J and Bienayme H 2005 Multicomponent reactions (Weinheim, Germany: Wiley-VCH)

3. (a) Dingermann T, Steinhilber D and Folkers G 2004 Molecular biology in medicinal chemistry (Weinheim: Wiley-VCH); (b) Shen A Y, Tsai C T and Chen C L 1999 Eur. J. Med. Chem. 34 877; (c) Shen A Y, Chen C L and Lin C I 1992 Chin. J. Physiol. 3545

4. Kantevari S, Vuppalapati S V N and Nagarapu L 2007 Catal. Commun. 81857

5. Selvam N P and Perumal P T 2006 Tetrahedron Lett. 47 7481

6. Nagarapu L, Baseeruddin M, Apuri S and Kantevari S 2007 Catal. Commun. 81729

7. Das B, Laxminarayana K, Ravikanth B and Rao B R 2007 J. Mol. Catal. A Chem. 261180

8. Nagawade R R and Shinde D B 2007 Acta. Chim. Slov. 54642

9. (a) Patil S B, Singh P R, Surpur M P and Samant S D 2007 Ultrason. Sonochem. 14 515; (b) Nagawade R R and Shinde D B 2007 Chinese J. Chem. 251710

10. (a) Mahdavinia G H, Bigdeli M A and Heravi M M 2008 Chinese Chem. Lett. 19 1171; (b) Shaterian H R, Yarahmadi H and Ghashang M 2008 Tetrahedron 64 1263

11. Shaterian H R, Yarahmadi H and Ghashang M 2008 Bioorg. Med. Chem. Lett. 18788

12. Nandi G C, Samai S, Kumar R and Singh M S 2009 Tetrahedron Lett. 507220

13. Shaterian H R and Yarahmadi H 2008 Tetrahedron Lett. 491297

14. Shaterian H R, Hosseinian A and Ghashang M 2008 Tetrahedron Lett. 495804

15. Jiang W Q, An L T and Zou J P 2008 Chinese J. Chem. 261697

16. Khodaei M M, Khosropour A R and Moghanian H 2006 Synlett 916
17. Dorehgiraee A, Khabazzade H and Saidi K 2009 ARKIVOC vii, 303

18. Supale A R and Gokavi G S 2010 J. Chem. Sci. 122189

19. Mahdavinia G H and Bigdeli M A 2009 Chinese Chem. Lett. 20383

20. Shaterian H R, Khorami F, Amirzadeh A and Ghashang M 2009 Chinese J. Chem. 27815

21. Ghorbani-Vaghei R and Malaekehpour S M 2010 Cent. Eur. J. Chem. 81086

22. Khazaei A, Zolfigol M A, Moosavi-Zare A R, Zare A, Parhami A and Khalafi-Nezhad A 2010 Appl. Catal. AGen. 386179

23. Khabazzadeh H, Saidi K and Seyedi N 2009 J. Chem. Sci. 121429

24. Patil S B, Singh P R, Surpur M P and Samant S D 2007 Synthetic Commun. 371659

25. Datta B and Pasha M A 2011 Ultrason. Sonochem. 18 624

26. Hong M, Cai C and Yi W B 2011 Chinese Chem. Lett. 22322

27. Wang M and Liang Y 2011 Monatsh. Chem. 142153

28. Zhang P and Zhang Z H 2009 Monatsh. Chem. 140199

29. Mistry S R, Joshi R S and Maheria K C 2011 J. Chem. Sci. 123427

30. Chavan N L, Naik P N and Nayak S K 2010 Synthetic Commun. 402941

31. Wang M, Song Z G and Liang Y 2012 Synthetic Commun. 42582

32. (a) Hajipour A R, Ghayeb Y, Sheikhan N and Ruoho A E 2009 Tetrahedron Lett. 50 5649; (b) Sapkal S B, Shelke K F, Madje B R, Shingate B B and Shingare M S 2009 Bull. Korean Chem. Soc. 30 2887; (c) Rashinkar G and Salunkhe R 2010 J. Mol. Catal. A- Chem. 316 146; (d) Luo J and Zhang Q 2011 Monatsh. Chem. 142 923; (e) Zhang Q, Luo J and Wei Y 2010 Green Chem. 12 2246; (f) Heravi M M, Tavakoli-Hoseini N and Bamoharram F F 2011 Synthetic Commun. 41298

33. Chaudhuri M K, Hussain S, Kantamb M L and Neelima B 2005 Tetrahedron Lett. 468329

34. Chaudhuri M K and Hussain S 2007 J. Mol. Catal. AChem. 269214

35. Kondaiah G C M, Reddy L A, Babu K S, Gurav V M, Huge K G, Bandichhor R, Reddy P P, Bhattacharya A and Anand R V 2008 Tetrahedron Lett. 49106

36. Kumar J S, Jonnalagadda S C and Mereddy V R 2010 Tetrahedron Lett. 51779

37. Rostami A and Akradi J 2010 Tetrahedron Lett. 513501

38. Tu S, Fang F, Miao C, Jiang H, Feng Y, Shi D and Wang X 2003 Tetrahedron Lett. 446153

39. Zhou X, Zhang M Y, Gao S T, Ma J J, Wang C and Liu C 2009 Chin. Chem. Lett. 20905

40. Shinde P V, Sonar S S, Shingate B B and Shingare M S 2010 Tetrahedron Lett. 511309 